\title{
THE CONSERVATION DILEMMA
}

\author{
Wesley E. Higgins ${ }^{1,3}$ \& George D. GanN ${ }^{2}$ \\ ${ }^{1}$ Center for Tropical Plant Science \& Conservation \\ Marie Selby Botanical Gardens, 811 South Palm Avenue, Sarasota, FL 34236, U.S.A. \\ ${ }^{2}$ The Institute for Regional Conservation \\ 22601 S.W. 152 Ave., Miami, Florida 33170 , U.S.A. \\ ${ }^{3}$ Author for correspondence: whiggins@selby.org
}

\begin{abstract}
RESUMEN: Aunque el Estado de Florida (Estados Unidos) ha adoptado las directrices de la UICN en cuanto a la aplicación de los criterios de conservación relacionados a su fauna, existe un vacío en términos de que ciertas especies pueden ser protegidas a pesar de no encontrarse en la lista de especies amenazadas y recibir algún nivel de protección. El Parque Nacional Everglades (Florida) es un hábitat crítico para un número de especies raras y otras varias docenas enlistadas como En Peligro o Amenazadas. Sin embargo, un dilema es la interacción entre especies. En este caso, la mosca endémica Melanagromyza miamensis oviposita sus huevos en la inflorescencia de la orquídea Trichocentrum undulatum. En ella, las larvas se desarrollan generalmente matando al tallo. Este es un ejemplo de la interacción entre dos especies, una ampliamente distribuida pero localmente incluida bajo la categoría de Críticamente Amenazada (CR) (T. undulatum) y la especie endémica (M. miamensis). De esta manera, se utiliza este ejemplo para demostrar la complejidad en el desarrollo de un plan de manejo.
\end{abstract}

KEY WoRDS: conservation, Everglades National Park, Melanagromyza miamensis, Trichocentrum undulatum

\section{Introduction}

The historic Everglades are a vast wetlands of international significance. South Florida is one of the most biologically diverse regions in North America, harboring over 1,400 species of native plants. Everglades National Park, the largest subtropical wilderness in the United States, constitutes a single, biotic engine that drives the systems that support all life in South Florida. The area boasts many rare and endangered species. The commingling of tropical and temperate plants, alligators and crocodiles, freshwater and saltwater swamps is found nowhere else on Earth. It has been designated an International Biosphere Reserve, a World Heritage Site, and a Wetland of International Importance, in recognition of its significance to all the people of the world. As such, this unique ecosystem has been the focus of the largest hydrologic restoration program ever attempted. The Comprehensive Everglades Restoration Plan (CERP) will provide multiple benefits to the south Florida ecosystem. With the implementation of the plan, improvements will be made by restoring natural flows of water, water quality and hydroperiods, improving the health of the south Florida ecosystem including the Everglades and Biscayne National Park, improving hydrologic conditions which will result in Lake Okeechobee once again becoming a healthy lake, and improving health of native flora and fauna populations including the threatened and endangered species.

History. Water is the lifeblood of the South Florida ecosystem. The Central and Southern Florida (C\&SF) Project was first authorized by Congress in 1948 as a multi-purpose project intended to provide flood control; water supply for municipal, industrial, and agricultural uses; prevention of saltwater intrusion; a water supply for Everglades National Park; and protection of fish and wildlife resources. The primary system included about 1,000 miles of levees, 720 miles of canals, and almost 200 water control structures. Although the U.S. Army Corps of Engineers had good intentions, the results have been disastrous. Not only does approximately 70 percent less water flows through the ecosystem today as compared to the historic Everglades, but the quality of the water that does enter the ecosystem has been seriously degraded. It does not follow the tim- 
ing and duration of the historical Everglades, nor can water move freely throughout the entire system. The whole South Florida ecosystem has suffered. The health of Lake Okeechobee, the second largest freshwater lake wholly in the United States, and an important home to fish and wildlife, is seriously threatened. A number of plants and animals that live in South Florida and the Everglades are in danger of becoming extinct because their habitat has been damaged, reduced, or eliminated. Clean water is not available to the estuaries and bays that are critical nurseries and homes to many fish and wildlife. Nor is there enough water for the humans. Water shortages and water restrictions are now a way of life in South Florida.

The Dilemma. Conflicting goals of habitat restoration, flood control, water storage, and transportation compete with prioritization of resource allocation. Within habitat restoration, priorities must be set to determine which species need intervention and what actions should be taken. The U.S. Army Corps of Engineers, in partnership with the South Florida Water Management District, has developed a Comprehensive Everglades Restoration Plan (CERP) to save the Everglades. Two aspects of the plan are considered here: waterflow and habitat restoration.

From a conservation standpoint restoring the southward flow of water is simply a matter of removing the obstacles to southward waterflow (dikes and roads) and plugging east-west diversions (canals and waterways). However, the dikes retain water for agricultural and municipal storage in the dry season and flood control in the wet season. The agricultural muck areas south of Lake Okeechobee were historically subject to sheet flow in the rainy season. Two major east-west roads in South Florida impede waterflow: I-75 and US-41. Numerous canals in developed areas of South Florida drain residential areas by cutting through the coastal ridge, diverting waterflow into the ocean. The Okeechobee Waterway connects the east and west coasts of Florida by connecting Lake Okeechobee to the Caloosahatchee River and the St. Lucie Canal, which connects Stuart, Florida, to Lake Okeechobee. The effects of these man-made changes have caused significant alterations in the timing (excess wet season flows, insufficient dry season flows), distribution, quality, and volume of freshwater entering the estuar- ies. Excess water during rainy seasons produces low salinity levels that are unable to support marine aquatic life, while severe low flows during the dry season causes salinity levels to spike. The goal of CERP is to redirect fresh water to areas that need it most.

\section{Saving the Everglades}

The Institute for Regional Conservation (IRC), based in Miami, Florida, is dedicated to the protection, restoration, and long-term management of biodiversity on a regional basis. Their work is premised on an innovative idea of conservation that seeks to protect and restore viable populations of all plant and animal species within a region. Unfortunately, habitat destruction, collecting, hydrological modifications, fire suppression, and other human activities have heavily disturbed, if not critically imperiled, many of South Florida's ecosystems, thus threatening many native plant species. There is an alarming loss of species. Over 100 species of native plants (8\%) are apparently extirpated in the region. Another 244 species $(17 \%)$ are Critically Imperiled, using Natural Heritage Program criteria. Epiphytes, including rare tropical orchids, ferns, and bromeliads, are more likely to be extirpated or critically imperiled than terrestrial plants. Most apparent extirpations have occurred in the last fifty years, which coincides with the C\&SF Project. Fortunately, only one endemic South Florida species, the Narrowleaf Hoarypea (Tephrosia angustissima Shuttlew. ex Chapm. var. angustissima [Gann et al. 2002]), is presumed to be extinct.

Initial Management Plan. Conservation management plans are regional strategies that provide an overview of conservation issues and give direction for the management of public conservation land and waters, as well as of species that are threatened. The strategies are a guide for both conservation managers and the public, indicating what managers intend to do, how priorities will be set, and how managers can respond to requests to use the natural resources they manage: in other words, how to reconcile conservation of biological resources with their sustainable use.

The IRC is dedicated to long-term management of biodiversity throughout South Florida. Their plan is based on the following methods: collecting baseline 
scientific data; assessing, planning and providing technical support for conservation; designing and implementing ecological restoration projects and long-term management programs; monitoring the effects of conservation projects on rare species and ecosystems and assessing needs for adaptive management; providing public education and publishing the results of their work online and in technical and popular journals; and nurturing a conservation aware community. The specific activities include

- conducting floristic inventories on conservation lands without plant data,

- conducting plant surveys on accessible private lands,

- mapping and monitoring rare plants,

- acquiring sites with populations of critically imperiled plants,

- developing conservation agreements with private landowners,

- stopping avoidable losses of rare plant populations in conservation areas,

- preventing poaching,

- controlling exotic pest plants and feral animals,

- restoring key habitats for rare plants in South Florida,

- restoring viable populations of critically imperiled plants,

- improving funding for rare plant conservation and restoration,

- developing and managing off-site collections of rare plants,

- educating the public and policy makers about the importance of native plants and rare plant conservation.

\section{Marie Selby Botanical Gardens' Collaboration}

The involvement of the scientists at Marie Selby Botanical Gardens (MSBG) with the Everglades restoration includes surveying populations, developing and managing ex situ collections of critically imperiled plants, and propagating germplasm for reintroduction. Presently, MSBG is propagating three imperiled ferns: Pecluma plumula (Humb. \& Bonpl. ex Willd.) M.G.Price, the plumed rockcap fern; Adiantum melanoleucum Willd., the fragrant maidenhair fern; Thelypteris reticulata (L.) Proctor, the lattice-vein fern; and two orchids: Brassia caudata (L) Lindl., the Spider orchid (a Jamaican plant); and
Oncidium ensatum Lindl., the Florida dancing-lady orchid. The fern spores and orchid seed have germinated. The fern spores were sown in pasteurized potting mix and the orchid seeds were germinated asymbiotically in-vitro.

The main concern about the reintroduction of a plant that has been extirpated from South Florida is the source of genetic material to be used for restoration. If the plant is a tropical species at the northern limit of its range, this can be a major problem. This is the case for many tropical ferns and orchids that have been extirpated from South Florida. These tropical species almost certainly arrived in South Florida from the Bahamas and Cuba; thus Bahamian or Cuban germplasm would have to be considered as appropriate sources of propagules. The Brassia caudata, being propagated by MSBG is a plant of Jamaican origin that has the same characteristics as the extirpated Florida species.

Data Deficient Species. In the 1920s, G. Moznette collected a specimen of an unknown fly in Dade County, Florida. The specimen was deposited at National Museum of Natural History (USNM), Washington DC. Moznette labeled the specimen "orchid - larva destroys bloom." The specimen remained unidentified until 1973 when Spencer described it as a new species of Agromyzidae. Externally the fly closely resembles Melanagromyza

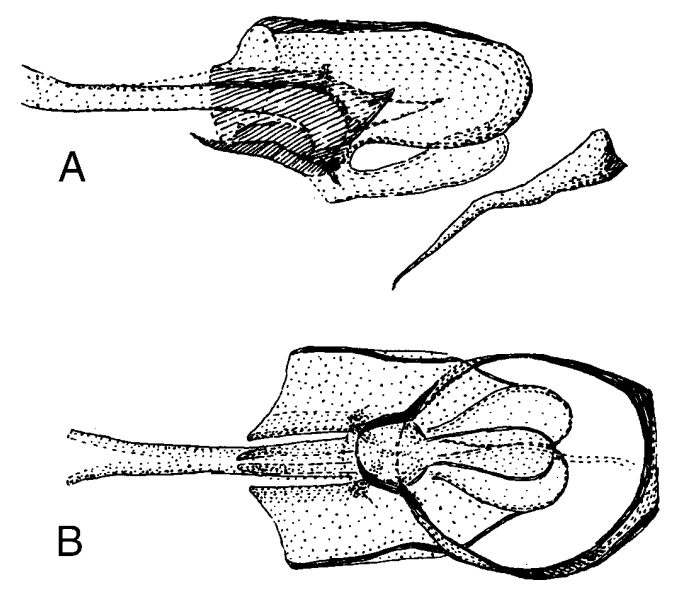

Figure 1. Distinct male genitalia (aedeagus) of Melanagromyza miamensis (Spencer 1973). A. side view. B. ventral view. 


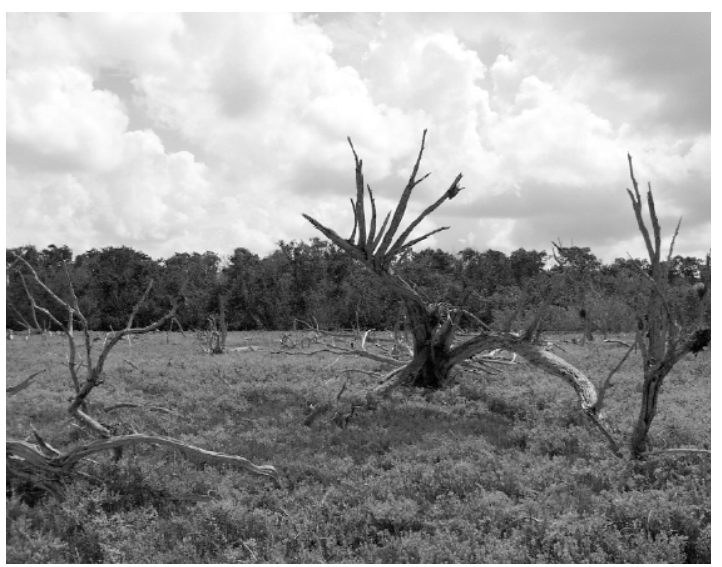

FIGURE 2. Dying buttonwood (Conocarpus erectus) forest converting to a saltwort marsh (Batis maritima). Photo by Wesley Higgins.

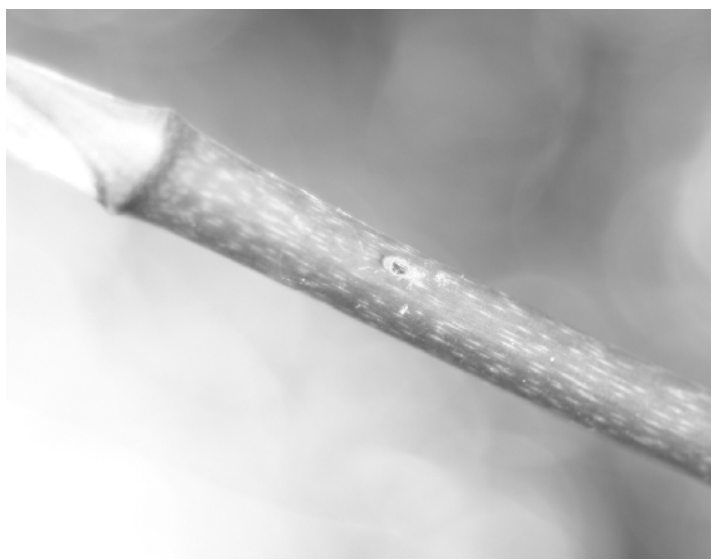

FIGURE 3. Site where Melanagromyza miamensis oviposited its eggs into the Trichocentrum undulatum stalk. Photo by Bruce Holst.

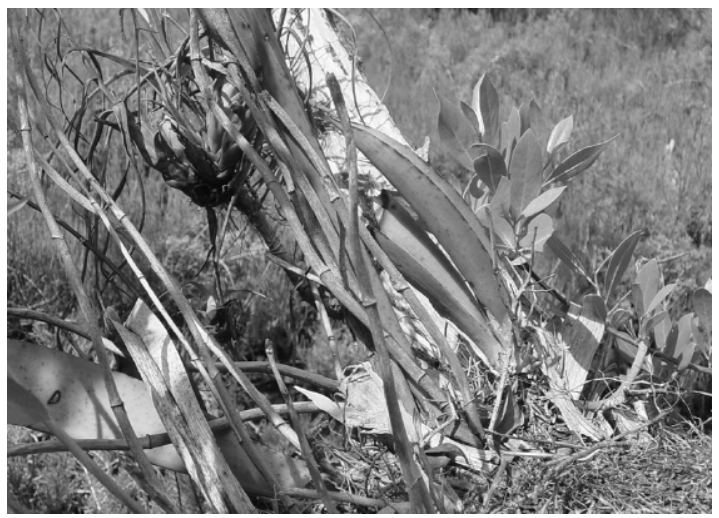

FIGURE 4. When ovipositing occurs below the $5^{\text {th }}$ node, it usually kills the Trichocentrum undulatum inflorescence. Photo by Wesley Higgins. floridensis Spencer; however, the male genitalia are entirely distinct (Fig. 1). Spencer proposed that the fly was a seed feeder and may feed on other epiphytic orchids in South Florida. The fly, possibly endemic to the Flamingo area of Everglades National Park, is not listed in USFWS Threatened and Endangered Species System (TESS). Using IUCN criteria this species is data deficient.

Critically Imperiled species. This Critically Imperiled species selected for ex situ propagation is Trichocentrum undulatum (Sw.) Ackerman \& M.W.Chase. Only one known population occurs in Everglades National Park near Flamingo. This habitat is a coastal berm forest of Conocarpus erectus $\mathrm{L}$. (Buttonwood), where T. undulatum grows epiphytically. Historically, this species was also found in rockland hammocks further to the north. Trichocentrum undulatum is native to South Florida and the West Indies. Perhaps fewer than 500 plants exist in Everglades National Park today (R. Hammer in Gann et al., 2002). The major threats are habitat destruction (exotic pest plant invasions \& sea-level rise), reproduction interruption, and poaching. IRC has proposed to reestablish a viable population of $T$. undulatum in the Long Pine Key area, where it historically occurred, in case that the Flamingo population is lost due to sea-level rise.

Forest DeCLine. Although Buttonwood is salt tolerant and thrives in soils that are acidic to alkaline, clayey to sandy, and dry to wet, there is generalized forest decline in the coastal berm site where Trichocentrum undulatum occurs. The area is converting to a saltwort marsh of Batis maritima L. as the trees die (Fig. 2). This is presumably caused by a combination of increased salinity due to a disruption of fresh water flow and sea level rise. A site survey reveals that as the buttonwood trees lose their canopy, the orchids are exposed to excessive sunlight and die.

Species Interaction. Another factor threatening the Trichocentrum undulatum population is disruption of the orchid reproduction cycle by an insect. Rick and Jean Seavey, naturalists from Miami-Dade County, have reported an interesting fly/orchid association (2006). The fly, Melanagromyza miamensis Spencer, oviposites its eggs into the stalk (Fig. 3) where the lar- 


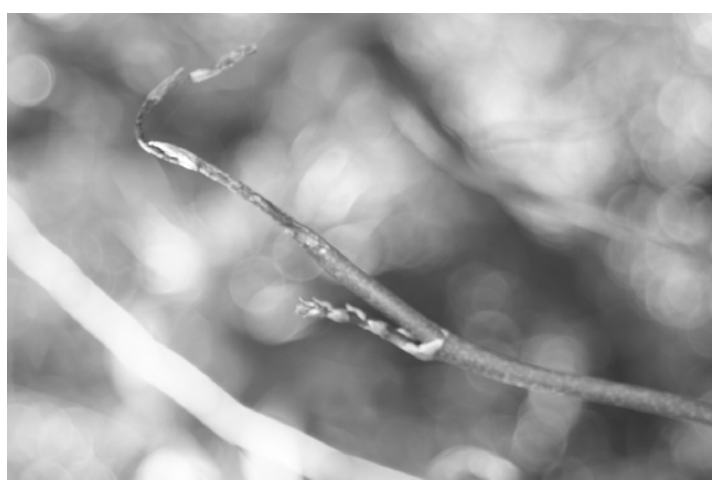

FIGURE 5. Trichocentrum undulatum plant generally develops side branches which are also attacked by the fly. Photo by Bruce Holst.

vae develop, later to emerge as adult flies. If ovipositing occurs below the $5^{\text {th }}$ node, it usually kills the inflorescence (Fig. 4). If entered above $5^{\text {th }}$ node, the plant generally develops side branches (Fig. 5) on the stalk, which are also attacked by the fly. This leads to either no flowers or an emaciated inflorescence. In 1998, only two plants flowered of 200 the Seaveys monitored. In 2006 the Trichocentrum undulatum population was surveyed and only one seed capsule (Fig. 6), the result of hand pollination, was found in the population. Despite the negative factors, recruits (seedlings and young plants) can be found in the healthy areas of the buttonwood forest (Fig. 7). Several specimens of M. miamensis Spencer were collected in Everglades National Park, near Homestead (Dade County; E97000732; Ron Clouse, park employee; 28 February 1997). These specimens are deposited in the Florida State Collection of Arthropods (Fig. 8). The insect is very rare as this is only the second reported collection. The fly is possibly endemic to the Flamingo area of Everglades National Park.

PoACHING. Public education is the primary effort to stop poaching, but enforcement is limited by available resources. Access to the conservation areas is controlled in visitor areas by park rangers; however, backcountry access by sportsmen is generally unmonitored. National Park officers sporadically inspect sportsmen at recreation access gates but have inadequate personnel to provide full time monitoring for a park with 137 mi $(220 \mathrm{~km})$ of coastline; 484,200 acres $(196,000$ hectares) in Florida Bay and the Gulf of Mexico; 572,200 acres $(231,500$ hectares $)$ of sawgrass/freshwa-

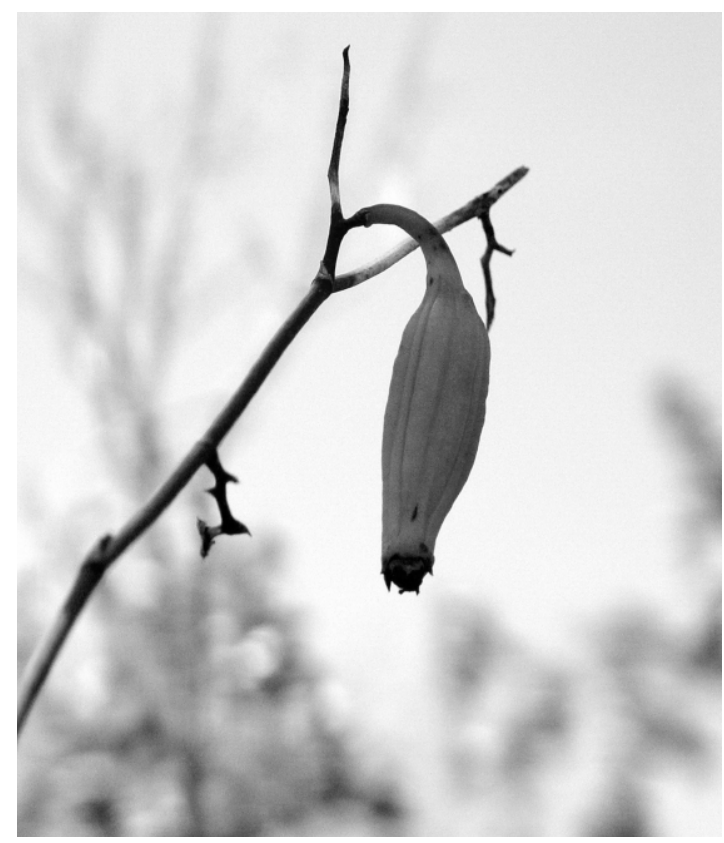

FiguRE 6. Only seed capsule in the extant Trichocentrum undulatum population in 2006. Photo by Wesley Higgins.

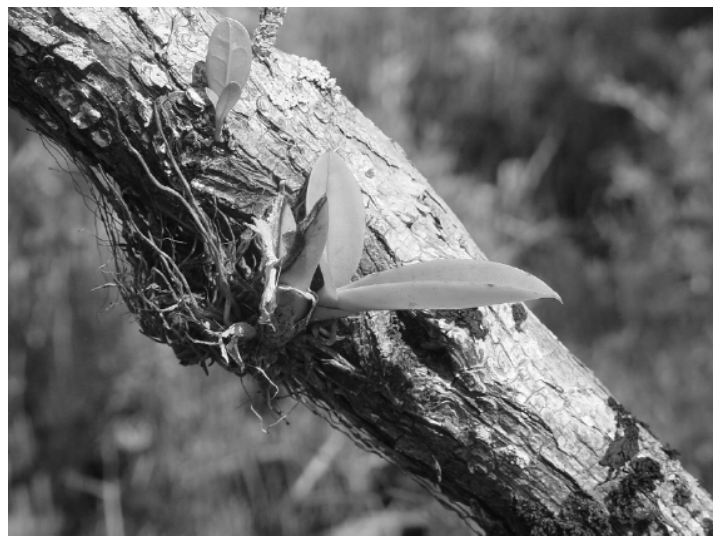

FIGURE 7. Trichocentrum undulatum recruits (seedlings and young plants) in the healthy areas of buttonwood forest. Photo by Wesley Higgins.

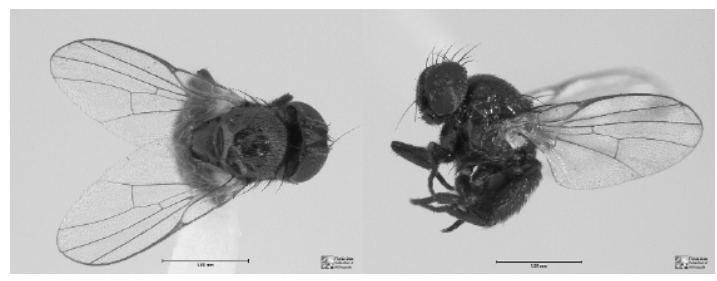

FIGURE 8 . This specimen of Melanagromyza miamensis is deposited in the Florida State Collection of Arthropods. Photo by Gary Steck. 
ter marsh; 230,100 acres $(93,100$ hectares) of mangrove forest; and 220,000 acres (89,000 hectares) of coastal areas (Cape Sable, river headwaters).

Habitat restoration. Although the state of Florida (USA) has adopted the IUCN guidelines for applying conservation criteria for animals, plants are regulated by the Florida Department of Agriculture and Consumer Services (FDACS) as endangered, threatened, or commercially exploited. For instance, although the buttonwood forests in Everglades National Park are in decline, the species, Conocarpus erectus, is not listed by FDACS; but is listed as Secure in South Florida by IRC since it occurs in most coastal counties of peninsular Florida. The orchid, Trichocentrum undulatum, is listed as Critically Imperiled by IRC and Endangered by the State of Florida; and the fly Melanagromyza miamensis is considered Data Deficient by authors. Presumably, if hydrological restoration is successful, ground water levels will be raised, wet season flows returned to transverse the everglades and fire intensities decreased, all to a degree that improves growing conditions for native species. The interaction between species is critical in habitat restoration. The fly reproduces in the orchid, which grows in the forest. Thus the Federal and State governments have made hydrological restoration a priority.

Future InTERVENTION. The Comprehensive Everglades Restoration Plan calls for restoration of hydroperiods as the initial step in habitat restoration. The inter-dependency of species, limits which interventions are appropriate (tree - orchid - fly). For example, application of a systemic insecticide may be beneficial to the orchid reproduction but detrimental to the fly. Researchers are proposing both in-situ and ex-situ intervention: hand pollination and reintroduction. Researchers can hand pollinate orchid flowers to increase fruit set, which may increase the availability of seed, depending on the degree of reproduction interruption by the fly. Ex-situ propagation of orchid seed to produce propagules for population augmentation may increase population if forest decline can be reversed. MSBG and IRC are investigating symbiotic germination of orchid seed using myrrchoizza fungi. Having the symbioant present may increase reintroduction success. Although the fly is data deficient, increasing the orchid population may also assist fly reproduction. This example of interaction between two species, one with widespread distribution but Critically Imperiled locally (T. undulatum), and a possibly endemic species (M. miamensis), is used to demonstrate the complexity of developing a management plan.

Acknowledgments. The IRC project, Rare Plant Monitoring and Restoration on Long Pine Key, Everglades National Park (ENP), is funded by ENP through the Critical Ecosystems Study Initiative. We thank Tom Armentano, retired from ENP, and ENP botanist Craig Smith for their collaboration, Lorena Endara for the Spanish translation of the abstract and Gary Steck for the photos of the Melanagromyza miamensis specimen.

\section{LiTERATURE CITED}

Gann, G. D., K. A. Bradley \& S. W. Woodmansee. 2002. Rare plants of South Florida: Their history, conservation, and restoration. Institute for Regional Conservation. Miami, Florida.

Comprehensive Everglades Restoration Plan (CERP). http://www.evergladesplan.org/. Accessed: May 2006.

Seavey, R. \& J. Seavey. 2006. Mule ear orchid new fly association. http://www.seaveyfieldguides.com/. Accessed: May 2006.

Spencer, K. A. 1973. Agromyzidae of Florida 7:43, in Arthropods of Florida. Florida Department of Agriculture and Consumer Services, Gainesville, Florida.

Wesley E. Higgins is the Head of Systematics at Marie Selby Botanical Gardens and the editor of Selbyana. His taxonomic interest is the systematics of Laeliinae based on holomorphology. He is best known for his taxonomic work with Prosthechea, Encyclia, Oestlundia, Dinema, and Microepidendrum. Wesley is also interested in orchid conservation and serves on the IUCN - Orchid Specialist Group.

George D. Gann is the Executive Director and co-founder of The Institute for Regional Conservation. He currently serves on the board of the Tropical Audubon Society and as Vice Chair of the Board of the Society for Ecological Restoration International (SER). He has received several awards for his work, including the Conservation Colleague Award from The Nature Conservancy, as well as the John Rieger Award for service and the Golden Trowel Award for special service to the Board of Directors from SER. 